\title{
The Use of Crude Coconut Oil (CCO) as an Alternative Oil Base Mud (OBM) for Drilling Operations by "VICOIL" Standard Drilling Simulation Rig
}

\author{
KRT Nur Suhascaryo ${ }^{1}$, Endah Wahyurini2, Yuan Cahyo Guntoro ${ }^{3}$ \\ 1, 3 Department of Petroleum Engineering, Faculty of Mineral Technology, UPN “Veteran” Yogyakarta, Indonesia \\ 2 Department of Agrotechnology, Faculty of Agriculture, UPN “Veteran” Yogyakarta, Indonesia
}

\begin{abstract}
Shale is one of the rocks that often causes drilling problems because shale tends to swell or swell when in contact with mud filtrate, mainly water-based or Water-base Mud (WBM). This study aims to determine how the performance of Oil-base Mud (OBM) based on Crude Coconut Oil (CCO) in overcoming the swelling problem. The methodology used consists of drilling simulation and cutting analysis in the X-Ray Diffraction (XRD) laboratory. The series of activities in the study began with the preparation of rock layers, followed by testing the penetration rate using Water-base Mud as a comparison. After cutting analysis was carried out in the XRD laboratory of UPN "Veteran" Yogyakarta with the Rigaku tool, then replaced the type of drilling fluid Oil-base Mud with basic materials alternative to Crude Coconut Oil (CCO) and followed by a penetration test. Rate of Penetration (ROP) test results from WBM with Rheology 1 at interval depth of $1.64 \mathrm{ft}-3.28 \mathrm{ft}$ is 442.8 $\mathrm{ft} / \mathrm{h}$, Rheology 2 at interval depth of $4.92-6.5 \mathrm{ft}$ is $118.5 \mathrm{ft} / \mathrm{hr}$ on the first day. Swelling occurred and results in pipe sticking at depth of 3.28 and $6.5 \mathrm{ft}$. Based on the Bulk Mineral analysis, clay mineral content is $23.84 \%$. Based on the Clay Oriented, smectite dominates the clay by $29.09 \%$. Based on MBT, shale belongs to class B (illite and mixed-layer montmorillonite illite), where this mineral can expand. Based on a Geonor As test, 5.18\% of the cutting can develop when exposed to water. The drilling fluid was replaced with Oil-base Mud based on alternative Crude Coconut Oil (CCO), and obtained ROP Rheology 1 at Interval depth of $3.28 \mathrm{ft}-4.92 \mathrm{ft}$ is $492 \mathrm{ft} / \mathrm{h}$ and Rheology 2 at Interval depth of $6.5 \mathrm{ft}-10.5 \mathrm{ft}$ is $480 \mathrm{ft} / \mathrm{h}$. The results of the Compressive Strength test interval A on the first, third, and fifth days were 31,699 psi, 42,265 psi, and 52,831 psi. The results of the Compressive Strength test interval B on the first, second, and third days were 31,496 psi, 41,517 psi, and 52,971 psi. Based on clay mineral analysis and magnitude of ROP value, is known that Crude Coconut Oil (CCO) based Oil- base Mud is effective because during the simulation, there are no drilling problems, and the resulting ROP value is greater than the first day Water-base Mud.
\end{abstract}

Keywords: Swelling, Minerals, Crude Coconut Oil, Oil Base Mud, Rate of Penetration

This is an open access article under the CC-BY-NC license

\section{INTRODUCTION}

Each type of drilling fluid has character, mainly in controlling hydrostatic pressure, which will affect the rate of penetration or Rate of Penetration (ROP) and its role in minimizing problems during drilling. Two drilling mud systems, namely water-base mud and oil-base mud. Some of the categories include air, water, and oil (Adams N J, 1985). Drilling mud depends on its physical and chemical properties. Problems are often found in the water-base mud (WBM), mainly in the shale zone. Drilling-grade bentonite is a naturally occurring clay containing the clay minerals of smectite. It can also contain accessory minerals, such as quartz, mica, feldspar and calcite. Shale layer swells or peels off when it comes into contact with water-based drilling mud. By definition, a high performance water-based system is supposed to emulate the performance of an invert fluid while eliminating most, if not all, of the risk and cost associated with managing wastes generated while drilling with invert emulsion systems.

Rate of penetration (ROP) is the volume of rock crushed per unit area (ft) per unit time (hours), or it can also be interpreted as the bit rate destroying the rock to be penetrated and in general ROP measures the speed or progress of the bit when drilling. Shale is a type of rock whose constituent minerals are mostly clay minerals. Swelling and sloughing are influenced by the mineral content in shale itself and the reactivity value of the clay. It is agreed on by many researchers (Yukselen and Kaya 2008; Muñoz et al. 2010; Nikolaides et al. 2007) that the methylene test is one of the most accurate and quickest methods in detecting clay minerals in aggregate fines. In drilling operation, there is direct contact between the

Corresponding author:

nur.suhascaryo@upnyk.ac.id 
circulating mud and the walls of the wellbore, resulting in a reaction that affects the properties of the mud, especially in drilling on shale or clay formation (argillaceous). The hydration phenomenon is caused by the interaction between drilling mud and argillaceous formation, which causes an increase in bulk volume of rock and expansion pressure. The conditions identified include the occurrence of sloughing, heaving, expansion (tight hole) and gradual whole enlargement and caving.

The use of oil-base mud has an unfavorable environmental impact, so that in several countries, regulations regarding its use have been enacted. Oil-base mud is more expensive than water-base mud. Coconut Crude Oil (CCO) or coconut oil is used as an alternative to mud oil-base hoping that the drilling operation process can be more effective. Coconut Oil or Crude coconut oil (CCO) is a processed product from coconut meat in the form of a clear liquid, tasteless liquid with a distinctive coconut odor. Crude coconut oil does not require expensive, because the raw materials are easy to obtain at low prices and simple processing. Pure coconut oil has chemical-physical properties, including organoleptic (colorless and needle-like crystals) and odor (there is a slightly sour smell plus a caramel smell). The solubility of CCO is insoluble in water, but soluble in alcohol (1:1). The specific gravity is 0.883 at $20^{\circ} \mathrm{C}$. The percentage of evaporation is that CCO does not evaporate at a temperature of $21^{\circ} \mathrm{C}(0 \%)$. The melting point is $20-25^{\circ} \mathrm{C}$, boiling point: $225^{\circ} \mathrm{C}$, and the density of air (Air=1): 6.91. Vapor pressure (mmHg) is one at $121^{\circ} \mathrm{C}$. CCO processing methods include fermentation methods, gradual heating, centrifugation, acidification and inducement.

X-Ray Diffraction (XRD) is an analytical method that is effective in describing rocks and certain chemical compounds in solid form by using X-ray diffraction/reflection. The basic law of using X-ray diffraction refers to Bragg's Law which is written with the formula $n \lambda=2 d \sin$ where $n$ is the order of fraction $(1,2,3, \ldots \mathrm{n})$, is the wavelength $(\AA), \mathrm{d}$ is the thickness of the unit cell , and is the diffraction angle.

This research aims to determine the performance of Crude Coconut Oil as an alternative material Oilbase Mud in overcoming swelling problems. The methodology used consists of drilling simulation and cutting analysis. The series of activities in the study began with the preparation of rock layers, penetration rate using Water-base Mud, cutting analysis was conducted in the X-Ray Diffraction Laboratory, Methylene Blue Test, and Geonor As analysis, then replaced the type of drilling fluid Oilbase Mud with alternative base material Crude Coconut Oil and continued with the penetration rate test.

\section{LITERATURE REVIEW}

\section{COMPRESSIVE STRENGTH}

The compressive strength is equal to the sum of the uniaxial compressive stresses, when the element under consideration is completely disconnected. (Davarpanah, Zarel, \& Nasabeh SM, 2016). Compressive strength generally increases with increasing depth, causing the rate of penetration (ROP) to decrease.

$$
\mathrm{Cs}=\mathrm{F} / \mathrm{A} \text {. }
$$

Where:

$$
\begin{aligned}
& \text { Cs = compressive strength, psi. } \\
& \mathrm{F} \quad=\text { strength or load at the point of damage, } \mathrm{N} . \mathrm{A}= \\
& \text { cross-sectionalload area, } \mathrm{m}^{2} \text {. }
\end{aligned}
$$

\section{X-Ray Diffraction (XRD) - Bulk Mineral}

$\mathrm{X}$-ray diffraction is a tool used to determine the mineralogy of sedimentary rocks. Monocormatic $\mathrm{x}$ - ray rays that penetrate the mineral grains, will be scattered by the atoms that make up the mineral. At a certain angle, the scattered x-ray beam will produce a secondary beam. This phenomenon is called diffraction. This relationship is written in the Bragg equation: 
Description:

$\mathrm{N} \lambda=2 \mathrm{~d} \sin \theta$

$\mathrm{d} \quad=$ Basalspacing

$\mathrm{n}=$ Fractionorder $(1,2,3, \ldots . \mathrm{n}) \lambda=$

Wave length, $\AA$

$\theta \quad=$ Shootingangle, ${ }^{\circ}$

Furthermore, to calculate the percentage of minerals in the sample, the following equation is used: $\mathrm{A}=I_{\mathrm{A}} /\left(I_{\mathrm{A}}+I_{\mathrm{B}}+\ldots . I_{\mathrm{n}}\right)$

$$
\times 100 \%
$$

Description:

$\mathrm{A}=$ Percent mineral (\%)

I = Shooting intensity (cps)

\section{Coconut Crude Oil (CCO)}

Coconut Oil or Crude coconut oil (CCO) is a processed product from coconut meat in the form of a clear, tasteless liquid with a distinctive coconut odor. The manufacture of Crude coconut oil does not require expensive costs, because the raw materials are easy to obtain at low prices and simple processing. Pure coconut oil has chemical-physical properties, including organoleptic (colorless and needle-like crystals) and odor (there is a slight sour smell plus a caramel smell). The solubility of CCO is insoluble in water, but soluble in alcohol (1:1). The specific gravity is 0.883 at $20^{\circ} \mathrm{C}$. The percentage of evaporation is that CCO does not evaporate at a temperature of $21^{\circ} \mathrm{C}(0 \%)$. The melting point is $20-25^{\circ} \mathrm{C}$, boiling point: $225^{\circ} \mathrm{C}$, and the density of air (Air=1): 6.91. Vapor pressure (mmHg) is 1 at $121^{\circ} \mathrm{C}$.

\section{Drilling Mud}

Drilling mud or fluid is a fluid that circulates in rotary drilling, which has various functions required in drilling operations. The type of drilling mud that is in accordance with the characteristics of the well will support the success of the drilling operation, especially on the flow pattern and drilling speed and the successful removal of cuttings to the surface (Coussot et al., 2004; Saasen et al., 2002).

There are two drilling mud systems, namely water base mud and oil base mud. Zaba and Doherty (1970) classified drilling mud mainly based on the fluid phase: water (water base), oil (oil base) or gas.

\section{"VICOIL" Standard Drilling Simulation Rig}

The "VICOIL" standard drilling simulation rig consists of a power system using a Honda C70 engine and a Dexta Cam Starter generator type QS5-15P/3. The Honda C70 engine has 71.8 cc engine specifications, type OHC, 4 stroke air conditioning, performance 6 hp @ 9000 rpm (power), 0.53 kg.m @ 7000 rpm (torque). The generator has $500 \mathrm{~V}$ and $15 \mathrm{~A}$ specifications. The supporting structure made of steel construction with a height of 3 meters, an area of $4 \mathrm{~m} 2$ (bottom) and $2 \mathrm{~m} 2$ (top). The substructure is made of an arrangement of 24 iron pipes measuring 1.25 inches with an area of $16 \mathrm{~m} 2$. The substructure is equipped with a cat walk with a height of $4 \mathrm{~m}$ and an iron construction ladder consisting of 15 steps. Rig floor has an area of $16 \mathrm{~m} 2$ of iron plate. On the hoisting equipment there is a modified drawwork made of the Honda C70 frame with dimensions of 1,805 $\mathrm{mm}$ (length), $685 \mathrm{~mm}$ (width), $995 \mathrm{~mm}$ (height). Suspension in the form of swing arm, double shockbreaker (front), leading link, and 2.2 inch travel (rear). Drum type brakes to help control speed. Rear tire size 2.50 - 17 - 6 PR. The overhead tool consists of a $12 \mathrm{~cm}$ diameter crown block, a modified hook with a direct drilling line belay, a modified traveling block with a rectangular shape measuring $1 \mathrm{~m}$ long, $15 \mathrm{~cm}$ wide and $30 \mathrm{~cm}$ high.

The drilling line consists of a fast line made of steel rope. The rotary assembly consists of a square turntable with a side length of $30 \mathrm{~cm}$. The turntable is connected to the generator via a belt on a 15 in diameter gear. The master bushing is square with a side length of $16 \mathrm{~cm}$. kelly bushings are rectangular in shape with a side length of $4 \mathrm{~cm}$. The drill pipe series consists of a rectangular kelly with a length of $9.8 \mathrm{ft}$, a drill pipe in the form of a 1.25 inch steel pipe with a length of $5.58 \mathrm{ft}$, and a modified drill collar in the form of a steel pipe thread measuring 1.25 inch with a length of $8.2 \mathrm{ft}$. The chisel (bit) is a modified drag bit with a steel cutter bit type with a three-blade design with a diameter of 4 inches. The preparation area for the circulation system consists of a tandone brand mud tank with a capacity of 350 liters equipped with a dynamo-powered agitator to stir the drilling fluid in the mud tank. Modern brand dynamo with type JY09A-4 with specifications HP, 220V, 50 HZ, 2.36A, 1400 RPM. The circulation 
equipment consists of a Shimizu brand mud pump model PS-226 BIT in the form of a water pump with a specification rate of $0.069 \mathrm{bpm}$ to $0.176 \mathrm{bpm}$. The conditioning area consists of a rectangular shale shaker with a double-layered iron wire filter measuring $30 \mathrm{~cm}$ wide and $40 \mathrm{~cm}$ long. There are setting tanks with a capacity of 70 liters used to accommodate mud during the conditioning area. The settling tanks are equipped with an InterNATIONAL type DB-125 water pump with a specification rate of $0.176 \mathrm{bpm}$.



Figure 1. "VICOIL" Standard Drilling Simulation Rig

\section{RESEARCH METHOD}

The method in this research is drilling simulation and laboratory test with the following steps:

\section{Arrangement of rock layers}

The preparation of this layer is intended to determine the effect of rock layer compactness on the penetration rate with drilling mud.

\section{Preparation of water-base mud (WBM)}

Preparation of water-base mud (WBM) which will be used for drilling and acts as a comparison for Oilbase Mud (OBM) made from Crude Coconut Oil (CCO).

\section{Rate of penetration}

This test was carried out using a standard drilling simulation rig, VICOIL, located at the Mineral Geotechnology Museum Park, UPN "Veteran" Yogyakarta. The drilling simulation tower is equipped with four drilling systems with modifications.

\section{Cutting analysis}

Cutting analysis was carried out using the X-Ray Diffraction method with the Rigaku tool.

- X-ray diffraction bulk mineral analysis

$\mathrm{X}$-ray diffraction analysis using bulk minerals is used to see the mineral content contained in the sample. X-ray diffraction is a tool used to determine the mineralogy of sedimentary rocks.

Monochromatic $x$-ray rays that penetrate the mineral, will be scattered by the atoms that make up the mineral. At a certain angle, the scattered x-ray will produce a secondary ray.

- X-ray diffraction clay oriented

After the mineral content based on bulk, minerals is known and if there is clay content, it must be continued with X-ray diffraction analysis using bulk minerals to see the clay content in bulk minerals.

- Methylene bluetest

The methylene blue (MBT) test was carried out to determine the cations that could be found and had indications of flake reactivity and swelling tendency. Based on the MBT value, the value of the cation exchange capacity will be obtained, which will later be used determine the appropriate type of shale.

- Geonor As

The mechanism of this test is sedimentation to see the large percentage of clay to swell when in contact with water.

2. Analysis of drilling problems is carried out based on data obtained during cutting analysis in the laboratory. 
RSF Conference Series: Engineering and Technology

Vol. 1 (1), 414-425

The Use of Crude Coconut Oil (CCO) as an Alternative Oil Base Mud (OBM) for Drilling Operations by "VICOIL" Standard Drilling Simulation Rig

KRT Nur Suhascaryo, Endah Wahyurini, Yuan Cahyo Guntoro

3. Changeofoil-basemuddrillingmudtypeand determination ofdrillingmud composition

Change a drilling mud and determine the composition of the drilling mud by identifyingthe potential problems seen from the XRD readings and also the target physical properties of the drilling mud to be achieved.

4. The physical properties of an effective CoconutCrude Oil-based oil-based mud can be determined based on the results of the penetration rate test with the "VICOIL" standard drilling simulation tower.

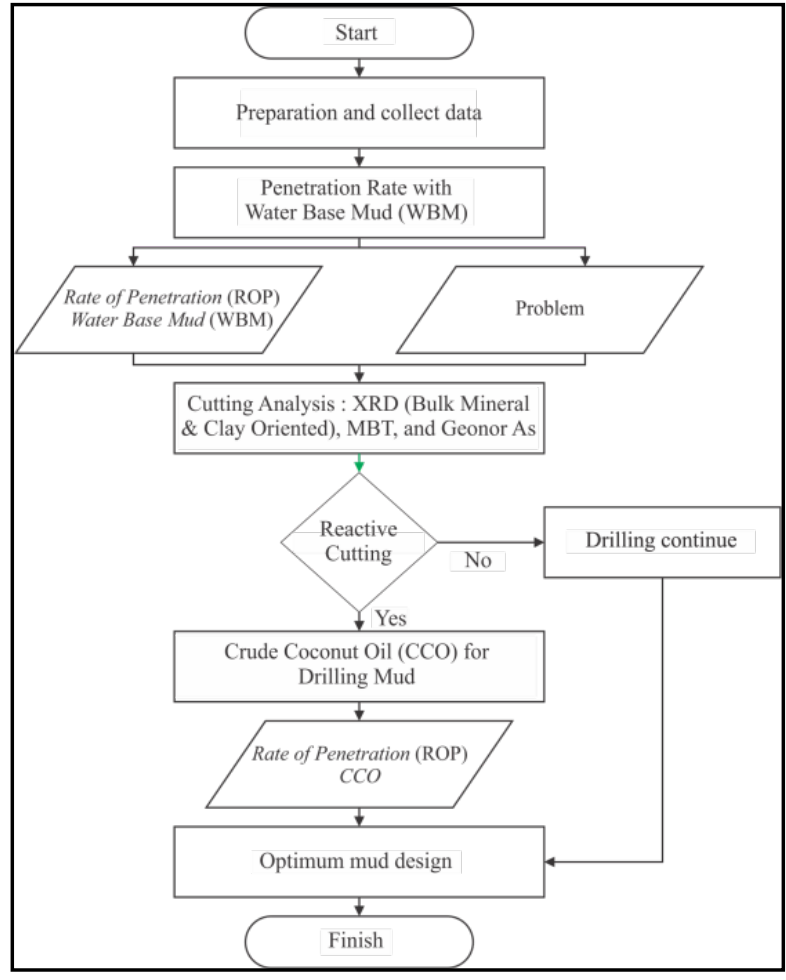

Figure 2. Flow Chart

\section{FINDING AND DISCUSSION}

Drilling Simulation by “VICOIL" Standard Drilling Simulation Rig Arrangement of Rock Layer

In the simulation well, two rock layers arranged in the form of shale and sandstone. First rock layers or interval A on depth 1.64-4.92 ft with a composition consisting of $6.6 \mathrm{~kg}$ or $37 \%$ shale, $5.5 \mathrm{~kg}$ or $49 \%$ sand, and $1.7 \mathrm{~kg}$ or $14 \%$ cement. Second rock or interval B layer on depth 4.92-10.5 ft with a composition consisting of $23.1 \mathrm{~kg}$ or $41 \%$ shale, $27.5 \mathrm{~kg}$ or $42 \%$ sand, and $8.5 \mathrm{~kg}$ or $17 \%$ cement. This simulation is six shale layers, where two insert shale lies at the middle and bottom of interval A and four layers of shale on interval B at of 6 $\mathrm{ft}-6.6 \mathrm{ft}, 6.8 \mathrm{ft}-7.5 \mathrm{ft}, 7.7 \mathrm{ft}-8.3 \mathrm{ft}$, and $8.5 \mathrm{ft}-8.8 \mathrm{ft}$. The results of Compressive Strength interval A testing on the first, third and fifth day is 31,699 psi, 42,265 psi, and 52,831 psi. The results of the Compressive Strength interval B testing on the first, second and third day is 31,496 psi, 41,517 psi, and 52,971 psi.

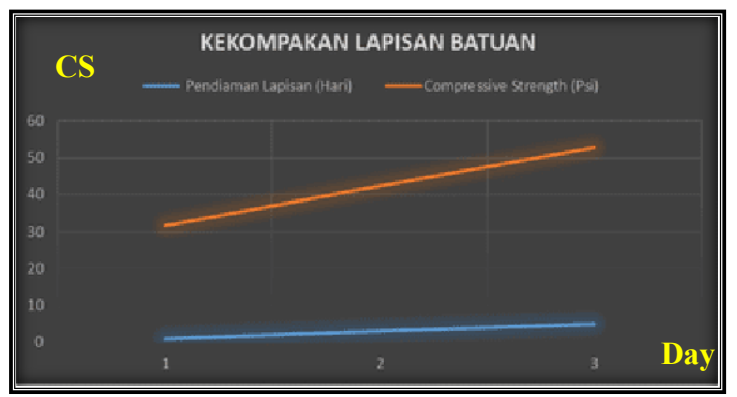

(a)

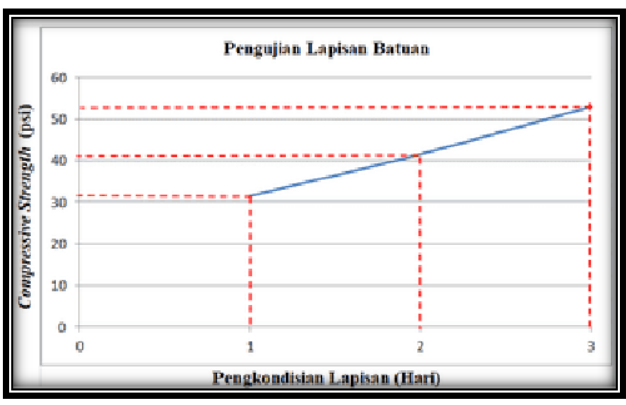

(b)

Figure 2. Comparison of Compressive Strength to Well Layer A (left) and B (right) Conditioning. (a) Compressive Strength layer A (b) Compressive Strength layer B. 


\section{Penetration Rate Testing with Water Base Mud}

The rock layer testing was carried out after the rock layers were arranged in a 4-inch diameter simulation well using a standard "VICOIL" drilling simulation rig. The optimum WOB value at WBM used is 7,136 lb for interval A and 32,34 lb for interval B, optimum value for RPM is $147 \mathrm{rpm}$. The mud pump used has a rate of $0.069 \mathrm{bpm}$. The optimum annular speed is $5.4 \mathrm{ft} / \mathrm{min}$. The modified Drag Bit size used is 3-inches. The volume of drilling mud used in this simulation is 17.97 liters of interval A and 38.92 liters of interval B. Here is rheology WBM 1 for interval A and rheology 2 for interval B.

Table I. Composition of Water Base Mud (WBM) Simulation

\begin{tabular}{|c|c|c|c|c|}
\hline \multicolumn{5}{|c|}{ Composition of Water-base Mud A and B } \\
\hline \multirow{2}{*}{ Ingredient } & \multicolumn{2}{|c|}{ Interval A } & \multicolumn{2}{|c|}{ Interval B } \\
\hline & \multicolumn{4}{|c|}{ Amount } \\
\hline Water & 17.97 & liter & 38.92 & liter \\
\hline Bentonite & 1147.5 & gram & 2502.0 & gram \\
\hline $\mathrm{KOH}$ & 25.5 & gram & 55.6 & gram \\
\hline PAC-L & 127.5 & gram & 336.6 & gram \\
\hline PAC-R & 127.5 & gram & 336.6 & gram \\
\hline KCL & 255 & gram & 667.2 & gram \\
\hline
\end{tabular}

Table II. Comparison of WBM Rheology Test Results

\begin{tabular}{|c|c|c|c|c|c|}
\hline \multicolumn{6}{|c|}{ Rheology Water Base Mud Comparison by “VICOIL" Drilling Simulation Rig } \\
\hline No. & Properties & Rheology $\mathbf{1}$ & $\begin{array}{c}\text { Rheology } \\
\mathbf{2}\end{array}$ & API Spec & Unit \\
\hline 1 & Mud Weight & 8.6 & 8.9 & $8.8-9.6$ & $\mathrm{ppg}$ \\
\hline 2 & Plastic Viscosity & 13 & 10 & $8-10$ & $\mathrm{cp}$ \\
\hline 3 & Yield Point & 12 & 14 & $<24$ & $\begin{array}{c}\mathrm{lb} / 100 \\
\mathrm{ft} 2\end{array}$ \\
\hline 4 & $\begin{array}{c}\text { GelStrength (10sec/10 } \\
\text { min) }\end{array}$ & $1 / 2$ & $2 / 4$ & $2-3 / 4-5$ & $\mathrm{lb} / 100 \mathrm{ft} 2$ \\
\hline 6 & Filtration loss & 6.8 & 6.2 & $<15$ & $\begin{array}{c}\mathrm{ml} / 30 \\
\mathrm{~min}\end{array}$ \\
\hline 7 & Filter Cake Thickness & 0.285 & 0.22 & $<4$ & $\mathrm{~mm}$ \\
\hline 8 & pH & 9 & 10 & $9.5-11.5$ & \\
\hline
\end{tabular}

TableIII.ResultsofWBMRheology1and2PenetrationRateontheFirstDay

\begin{tabular}{|c|c|c|c|}
\hline Depth (ft) & $\begin{array}{c}\text { ROP (ft/h) Day 1 by } \\
\text { RheologyWBM 1 } \\
\text { Interval A }\end{array}$ & Depth (ft) & $\begin{array}{c}\text { ROP (ft/h) Day 1 by } \\
\text { RheologyWBM } \\
\text { 2 Interval B }\end{array}$ \\
\hline 2.94 & 944.64 & 5.5 & 348.0 \\
\hline 3.11 & 235.2 & 6 & 150.0 \\
\hline 3.28 & 176.4 & 6.5 & 60.0 \\
\hline
\end{tabular}

Table IV. WBM Rheology 1 and 2 Total of Penetration Rate Results

\begin{tabular}{|c|c|c|c|}
\hline \multicolumn{4}{|c|}{ WBM Testing } \\
\hline Rheology & Day & Depth (ft) & ROP Total (ft/h) \\
\hline 1 & 1 & 3.28 & 442.8 \\
\hline 2 & 1 & 6.5 & 118.5 \\
\hline
\end{tabular}

Table 1 is the composition of water-base mud used in drilling intervals A and B. Table 2 is a waterbased mud rheology used in drilling simulations where rheology 1 is for interval A and rheology 2 is for interval B. Table 3 is the result of penetration rate with water-base mud with rheology 1 and 2 at each depth interval. During testing with WBM, a pipe sticking problem occurred in the middle of interval A or $3.28 \mathrm{ft}$ and in a depth of $6.5 \mathrm{ft}$ from surface. Table 4 is the result of total penetration rate 


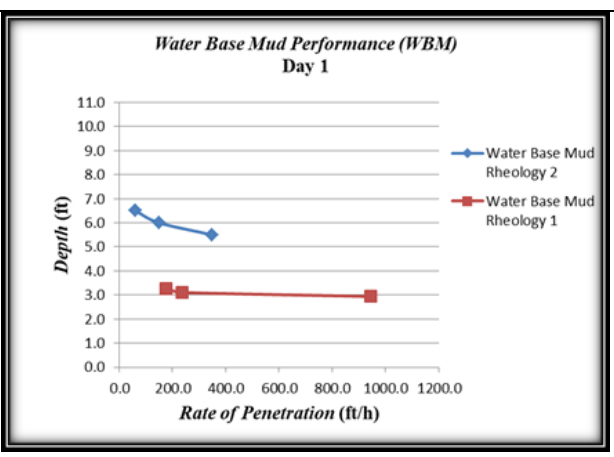

Figure 4. Comparison of Depth with Rate of Penetration Day 1 by Rheology 1 and 2

\section{Cutting Sample Analysis}

Cutting analysis is carried out to determine the type of rock layer that is penetrated. In this simulation, it is known that the drilling carried out penetrates the shale layer and there is an indication of swelling at a depth of 3.28 and $6.5 \mathrm{ft}$ which then occurs in pipe sticking. Cutting/samples were taken in a shale shaker and treated, cuttings were placed in an oven at $90 \mathrm{oC}$ to dry the cuttings, and then vacuum with a desiccator to remove the water content in the samples. The cuttings tested in this simulation show an indication of swelling, and this can be seen in Figure 4, which shows the development reaction when the model is dropped with water.

\section{XRD Bulk Mineral Analysis}

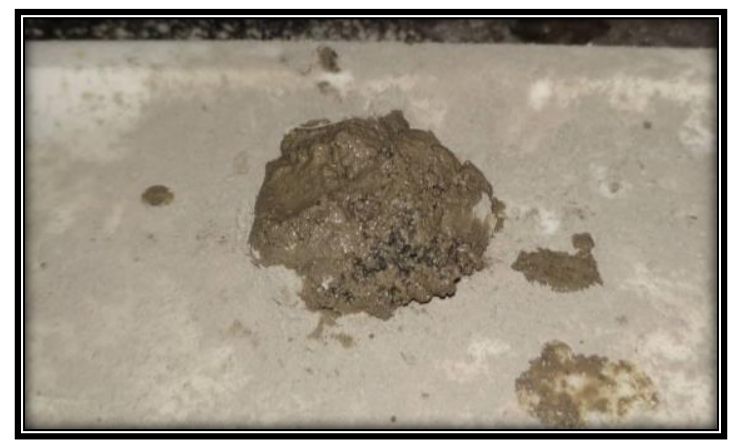

Cutting analysis was carried out using a Rigaku tool with a firing angle of 3o-90o. A graph is obtained after shooting the cutting sample, where this graph is a comparison between the intensity and the angle of shooting.

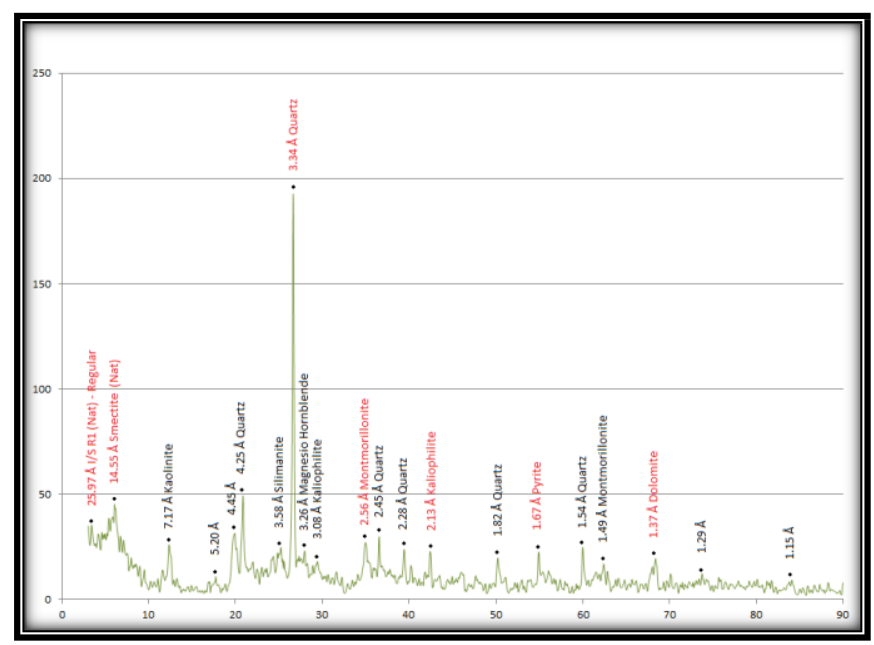

Figure 6. Results of Bulk Mineral Analysis

From this figure, it is known that the peak of the cutting interval is at a shooting angle of 26.680 with an intensity of $192.647196 \mathrm{cps}$. Then the calculation is carried out using the Bragg equation as follows: 


$$
\begin{gathered}
d=\frac{\lambda}{2 \sin \left[\frac{2 \theta(d e g)}{2}\right]} \\
d=\frac{1,5406 \mathrm{~nm}}{2 \sin \left[\frac{26.68}{2}\right]}
\end{gathered}
$$

$d=3.34 \AA$

It is known that the peak size indicates the percentage of minerals, it can be calculated by the following equation:

$$
\begin{aligned}
\text { Quartz Percent Mineral }= & \frac{\text { Quartz Intensity }(\mathrm{cps}) \times 100 \%}{\text { Total Intensity }} \\
& =\frac{192.647196}{365.24989} \times 100 \% \\
& =56.97 \%
\end{aligned}
$$

Table V. Cutting Analysis Results of Bulk Mineral XRD

\begin{tabular}{|c|c|c|c|c|c|}
\hline $\begin{array}{c}\mathbf{2} \boldsymbol{\theta} \\
(\mathbf{d e g})\end{array}$ & $\begin{array}{c}\text { Intensity } \\
\text { (cps) }\end{array}$ & $\mathbf{2} \boldsymbol{\theta} / \mathbf{2}$ & $\mathbf{d}$ & Mineral & $\begin{array}{c}\text { Percent } \\
(\mathbf{\%})\end{array}$ \\
\hline 3.4 & 35.371654 & 1.7 & 25.97 & I/S R1 (Nat) - Regular & 10.46 \\
\hline 6.07 & 45.259733 & 3.035 & 14.55 & $\begin{array}{c}\text { Smectite/ } \\
\text { Monmorillonite }\end{array}$ & 13.38 \\
\hline 26.68 & 192.647196 & 13.34 & 3.34 & Quartz & 56.97 \\
\hline 42.5 & 22.821814 & 21.25 & 2.13 & Kaliophilite & 6.75 \\
\hline 54.89 & 22.620702 & 27.445 & 1.67 & Pyrite & 6.69 \\
\hline 68.34 & 19.459853 & 34.17 & 1.37 & Dolomite & 5.75 \\
\hline
\end{tabular}

Based on Table $\mathbf{V}$, the percentages of various minerals in the analyzed cuttings were obtained. The mineral content of Clay in the cutting drilling by the "VICOIL" Driling Simulation Rig is quite large, namely $23.84 \%$, Quartz mineral contentis $56.97 \%$, Kaliophilitemineralcontentis $6.75 \%$, Pyrite mineral content is $6.69 \%$, and Dolomite mineral content is $5.75 \%$. Based on the Bulk Mineral Analysis, the high clay minerals can be analysis with ClayOriented.

\section{XRD Clay Oriented Analysis}

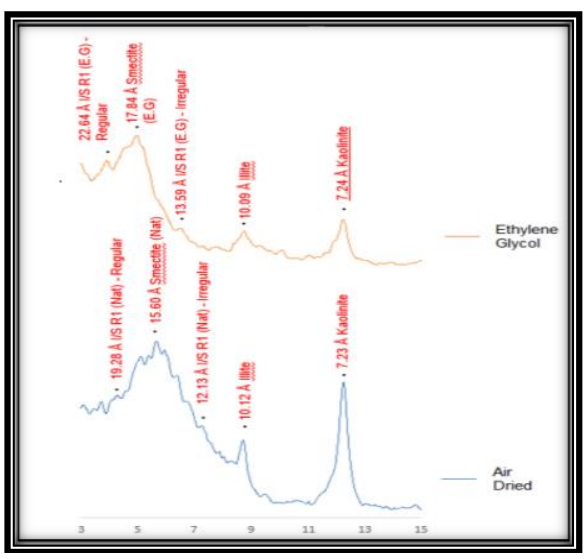

Figure 7. Results of Clay Oriented Analysis

Based on Clay Oriented, clay content dominated by smectite or montmorillonite $29.09 \%$. Cation Exchange Capacity from smectiteishigh, and thereis $70-130 \mathrm{meq} / 100 \mathrm{gr}$. 
RSF Conference Series: Engineering and Technology

Vol. 1 (1), 414-425

The Use of Crude Coconut Oil (CCO) as an Alternative Oil Base Mud (OBM) for Drilling Operations by "VICOIL" Standard Drilling Simulation Rig

Methylene Blue Test (MBT)

KRT Nur Suhascaryo, Endah Wahyurini, Yuan Cahyo Guntoro

From MBT analysis, titration every $2 \mathrm{ml}$ of methylene blue to sample of cutting. The result is $16 \mathrm{meq} /$ $100 \mathrm{gr}$, so the shale includes a B class (illite and mixed-layer montmorillonite illite), and from that, the shale can be swelling.



Figure 8. Results of MBT Test

\section{Geonor As}

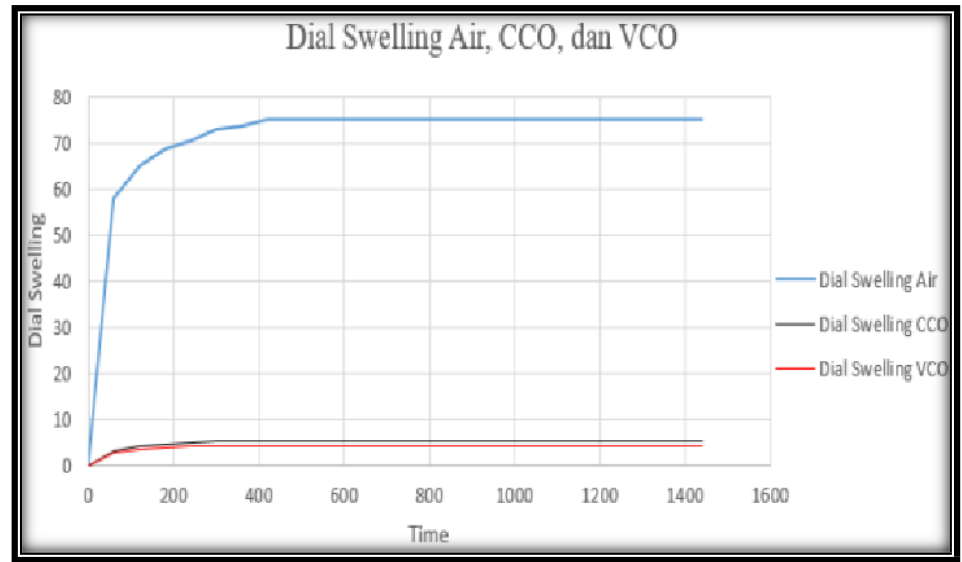

Figure 9. Dial Swelling Cutting

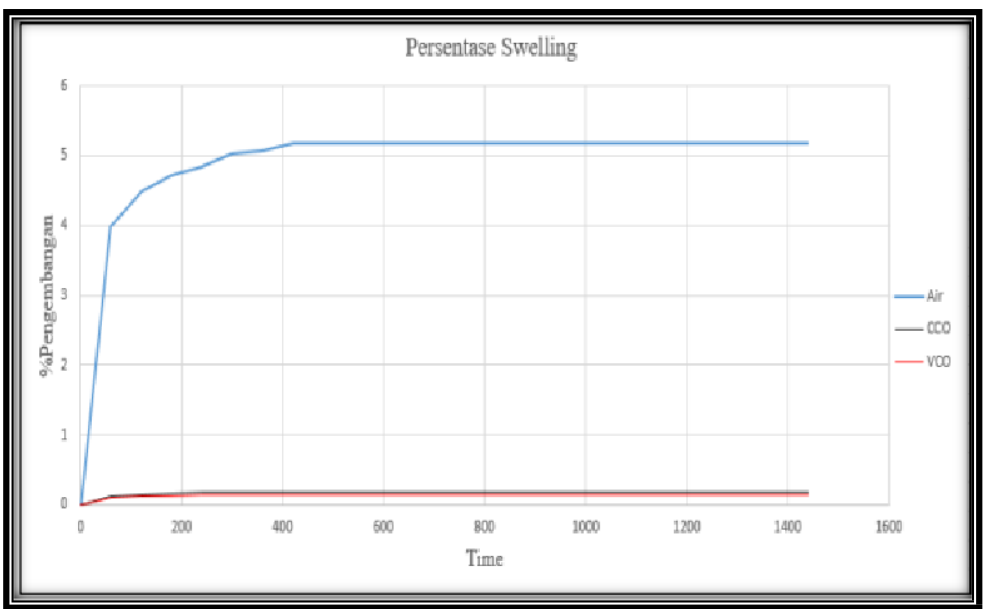

Figure 10. Percentage swelling cutting

Based on the swelling test with the Geonor As, the cutting sample is in contact with water, it will produce a swelling percentage of $5.18 \%$.

Testing the Penetration Rate Using Oil Base Mud (OBM) made from Alternative Crude Coconut Oil (CCO)

The penetration rate test uses Oil Base Mud (OBM) drilling fluid with alternative base materials of Crude Coconut Oil (CCO) or Coconut Oil. The volume of drilling mud used in this simulation is 38.92 . 
RSF Conference Series: Engineering and Technology

Vol. 1 (1), 414-425

The Use of Crude Coconut Oil (CCO) as an Alternative Oil Base Mud (OBM) for Drilling Operations by "VICOIL" Standard Drilling Simulation Rig

KRT Nur Suhascaryo, Endah Wahyurini, Yuan Cahyo Guntoro

Table VI. Composition of Oil Base Mud (OBM) Simulation by "VICOIL" Standard Simulation Rig

\begin{tabular}{|l|r|l|r|c|}
\hline \multicolumn{5}{|c|}{ Composition of Oil-base Mud interval A and B } \\
\hline \multicolumn{3}{|c|}{ Interval A } & \multicolumn{2}{c|}{ Interval B } \\
\hline \multicolumn{1}{|c|}{ Ingredient } & \multicolumn{2}{c|}{ Amount } & \multicolumn{2}{c|}{ Amount } \\
\hline CC0 & 5.55 & liter & 31.136 & liter \\
& 5.415 & liter & 7.8 & liter \\
\hline Water & 1530 & gram & 3892 & gram \\
\hline CaCl2 & 255 & gram & 556 & gram \\
\hline H-Lime & 5100 & gram & 11120 & gram \\
\hline Barite & 153 & gram & 333.6 & gram \\
\hline Geltone & 255 & gram & 667.2 & gram \\
\hline Carbotrol & 0.255 & liter & 0.6 & liter \\
\hline Invermul & 0.102 & liter & 0.2 & liter \\
\hline EZ Mul & & & & \\
\hline
\end{tabular}

Table VII. Comparison of Rheology Test Results by “VICOIL" Drilling Standard Simulation Rig

\begin{tabular}{|c|l|c|c|c|c|}
\hline \multicolumn{5}{|c|}{ Rheology Oil-base Mud } \\
\hline No. & \multicolumn{1}{|c|}{ Properties } & Rheology 1 & Rheology 2 & API Spec & Unit \\
\hline 1 & Mud Weight & 10.3 & 10.1 & $10-11$ & $\mathrm{ppg}$ \\
\hline 2 & Plastic Viscosity & 19 & 18 & $<35$ & $\mathrm{cp}$ \\
\hline 3 & Yield Point & 32 & 24 & $15-25$ & $\mathrm{lb} / 100 \mathrm{ft} 2$ \\
\hline 4 & $\begin{array}{l}\text { Gel Strength (10 sec/ 10 } \\
\text { min) }\end{array}$ & $12 / 16$ & $8 / 15$ & $\begin{array}{c}6-10 / 13- \\
18\end{array}$ & $\mathrm{lb} / 100 \mathrm{ft} 2$ \\
\hline 6 & Filtration loss & 3 & 3.8 & $<4$ & $\mathrm{ml} / 30 \mathrm{~min}$ \\
\hline 7 & Filter Cake Thickness & 1.7 & 1.8 & $<2$ & $\mathrm{~mm}$ \\
\hline 8 & pH & 8 & 6 & $8.5-9.5$ & \\
\hline
\end{tabular}

Table 6 is the composition of oil-base mud used in drilling intervals A and B. Table 7 is a oil-based mud rheology used in drilling simulations where rheology 1 is for interval A and rheology 2 is for interval B.

Table VIII. First, Second and Third Day Penetration Rate Results with OBM Rheology 1 and 2

\begin{tabular}{|c|c|c|c|}
\hline Rheolog & $\begin{array}{c}\text { Depth } \\
\text { (ft) }\end{array}$ & Day 1 ROP (ft/h) & Day 3 ROP (ft/h) \\
\hline \multirow{3}{*}{1} & 3.94 & 944.64 & 248.5 \\
\cline { 2 - 4 } & 4.43 & 271.3 & 160.3 \\
\cline { 2 - 4 } & 4.92 & 196 & 135.6 \\
\hline \multirow{3}{*}{2} & 7.00 & 900.0 & 197.1 \\
\cline { 2 - 4 } & 9.00 & 553.8 & 73.5 \\
\cline { 2 - 4 } & 10.5 & 360.0 & 37.5 \\
\hline
\end{tabular}

Table IX.Total Penetration Rate Results

\begin{tabular}{|c|c|c|c|}
\hline \multirow{2}{*}{ Rheology } & \multicolumn{3}{|c|}{ Total Penetration Rate OBM } \\
\cline { 2 - 4 } & Day & Depth (ft) & ROP (ft/h) \\
\hline \multirow{2}{*}{1} & 1 & 4.92 & 492 \\
\cline { 2 - 4 } & 3 & 4.92 & 264.3 \\
\hline \multirow{2}{*}{2} & 1 & 10.5 & 480 \\
\cline { 2 - 4 } & 3 & 10.5 & 71.7 \\
\hline
\end{tabular}






Figure 11. Oil Base Mud (OBM) Performance of Rheology 1 and 2

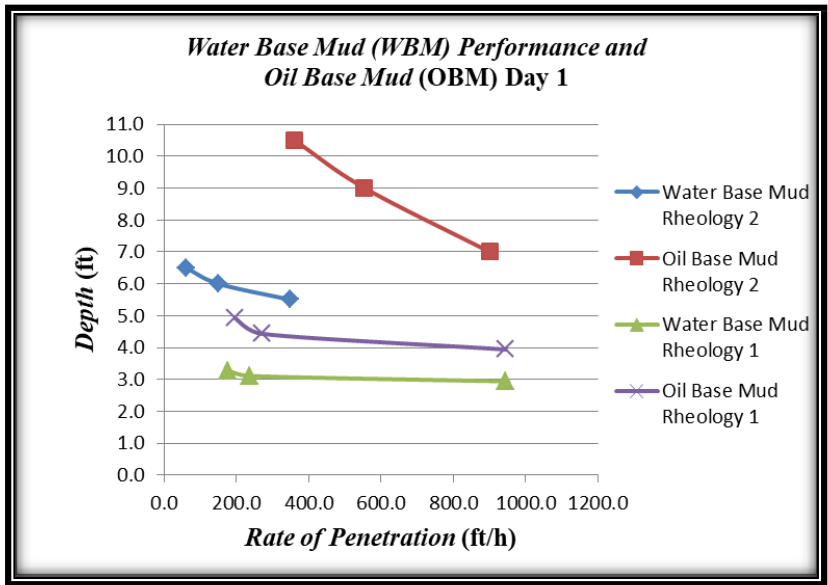

Figure 12. Comparison of the Performance of Water Base Mud (WBM) and Oil Base Mud (OBM) on the first day of Rheology 1 and 2

Based on the table 9 and 10, the total of penetration rate value generated while using OBM Rheology 1 on the first day of testing was $492 \mathrm{ft} / \mathrm{h}$ and the third day of testing was $264.3 \mathrm{ft} / \mathrm{h}$. The rate of penetration produced by OBM rheology 1 on the first day is greater than the use of WBM rheology 1. Penetration rate value generated while using OBM Rheology 2 on the first day of testing was $480 \mathrm{ft} / \mathrm{h}$ and the third day of testing was $71.7 \mathrm{ft} / \mathrm{h}$. he rate of penetration produced by OBM rheology 2 on the first day is greater than the use of WBM rheology 2. When the drilling simulation with OBM was carried out, there are no problems. Based on the value of the penetration rate with OBM, known that the penetration rate will decrease with increasing days, which is in line with the increase in the compressive strength value of the rock layer.

\section{CONCLUSION AND FURTHER RESEARCH}

The Compressive Strength (CS) Test Intervals on Days 1, 3 and 5 were 31,699 psi, 42,265 psi, and 52,831 psi. The results of the CS interval B test on the 1,2, and 3 days were 31,496 psi, 41,517 psi, and 52,971 psi. Rate of Penetration by WBM Day 1 with Rheology 1 was $442.8 \mathrm{ft} / \mathrm{hr}$, Rheology 2 was $118.5 \mathrm{ft} / \mathrm{hr}$.

Based on cutting analysis, the clay mineral component is $23.84 \%$, where smectite dominates $29.09 \%$, and cutting belongs to class B shale (illite and mixed-layer montmorilonite illite), where this mineral can expand. According to Geonor As, 5.18\% of cuttings can expand when exposed to water.

Rate of Penetration by OBM Rheology 1 was $492 \mathrm{ft} / \mathrm{hr}$, and Rheology 2 was $480 \mathrm{ft} / \mathrm{hr}$. The ROP of WBM is lower than OBM because the shale layer expands when it comes in contact with the WBM mud filtrate. Based on these results, it's known that the use of Oil-base Mud based on alternative Crude Coconut Oil (CCO) is effective. 


\section{REFERENCES}

Adams, N J 1985, 'Drilling Engineering,' A Complete Well Planning Approach Penn Well Publishing Co, Tulsa Oklahoma

American Petroleum Institute 2010, 'Specification for Drilling Fluids Specifications and Testing,' Dallas.

Baroid Fluid Services Fluids Handbook 2006, Halliburton Fluid Systems.

Bourgoyne, A T, Millheim, K K, Chenevert, M E, \& Young, F S 1991, 'Applied Drilling Engineering,' United States of America: Society Of Petroleum Engineers.

Davarpanah, A, Zarel, M, \& Nasabeh SM, M 2016, 'Assessment of Mechanical Specific Energy Aimed at Improving Drilling Inefficiencies and Minimize Wellbore Instability,' Journal of Petroleum \& Environmental Biotechnology 2.

Herianto, \& Askeyanto, D 2015, 'Analisa Swelling Clay Formasi Telisa Untuk Perencanaan Lumpur Pemboran,' Seminar Nasional Kebumian X - FTM - UPN "Veteran" Yogyakarta (p. 224)," Yogyakarta, FTM UPN "Veteran" Yogyakarta.

Pitre, Brandon Thomas 2012, 'Application of the modified Methylene Blue Test to detect clay minerals in coarse aggregate fines,' Texas A\&M University.

Suhascaryo, Nur 2020, 'The Effects of VICOIL Bopanprog Usage as a Substitute for Crude Oil for Oil-Based Drilling Fluids,' Proceeding on Engineering and Science Series (ESS), vol. 1, no. 1.

Suhascaryo, Nur, \& Yudiantoro, A 2020, 'Proses Aktivasi Dalam Peningkatan Kualitas VICOIL BOPANPROG Desa Bojong, Kecamatan Panjatan, Kabupaten Kulonprogo,' Yogyakarta: Uwais Inspirasi Indonesia.

Wicaksono, D D, Setiawan, N I, Wilopo, W, \& Harijoko, A 2017, 'Teknik Preparasi Sampel Dalam Analisis Mineralogi Dengan XRD (X-Ray Diffraction) Di Departemen Teknik Geologi, Fakultas Teknik, Universitas Gadjah Mada,' Seminar Nasional Kebumian Ke-10 (pp. 1864-1880). Yogyakarta: Universitas Gadjah Mada. 